\title{
STRATEGI PENGEMBANGAN KUALITAS BUMDES; PENDEKATAN MODEL TETRAPRENEUR SERTA KEMITRAAN DENGAN PERGURUAN TINGGI DAN PERBANKAN
}

\author{
Dien Noviany Rahmatika', Setyowati Subroto ${ }^{2}$, Dewi Indriasih ${ }^{3}$, Deddy Prihadi ${ }^{4}$ \\ Fakultas Ekonomi dan Bisnis Universitas Pancasakti Tegal \\ Jl. Halmahera No.KM, Mintaragen, Kota Tegal, Jawa Tengah \\ Email Korespondensi: diennovi@upstegal.ac.id,
}

\begin{abstract}
ABSTRAK
Satuan wilayah terendah dalam perangkat ketatanegaraan di Indonesia adalah Desa. Setelah lahirnya UU Desa, perkembangan di Pedesaan memasuki era baru yang diharapkan dapat mendorong Desa untuk menjadi mandiri secara sosial, budaya, ekonomi dan politik. Dengan kata lain Desa diberikan otonomi (kebebasan) untuk penyelenggaraan kepemerintahan. Bentuk pemberdayaan pemerintah berkaitan dengan otonomi Desa adalah dengan memberikan kewenangan pengelolaan sumber daya yang dimiliki oleh Desa secara mandiri dan adaptif dengan membentuk Badan Usaha Milik Desa (BUMDes). BUMDes merupakan salah satu lembaga ekonomi masyarakat yang memiliki peran cukup strategis dalam meningkatkan perekonomian masyarakat di pedesaan. Oleh karena itu, BUMDes perlu mengoptimalkan sumber daya yang dimilikinya untuk kesejahteraan masyarakat. Tujuan pengabdian pada masyarakat ini adalah melakukan pendampingan, pembinaan, monitoring BumDes dan mensosialisasikan bentuk strategi pengembangan BUMDes menggunakan Model Tetrapreneur dan pengembangannya dengan melibatkan Perguruan Tinggi dan Perbankan. Hasil dari pendampingan ini adalah diharapkan BumDes dapat lebih berhasil dalam kegiatannya, karena didampingi dari unsur akademisi dan perbankan. Dengan adanya BumDes yang maju maka perekonomian masyarakat desa ikut meningkat.
\end{abstract}

Kata Kunci: Strategi Pengembangan BUMDes, Tetrapreneur, Perguruan Tinggi, dan Perbankan

\begin{abstract}
The lowest regional unit in the constitutional apparatus in Indonesia is the Village. After the enactment of the Village Law, developments in Rural areas entered a new era which was expected to encourage villages to become independent socially, culturally, economically and politically. In other words, villages are given autonomy (freedom) for governance. The form of government empowerment related to Village autonomy is by giving the authority to manage resources owned by the Village independently and adaptively by forming Village-Owned Enterprises (BUMDes). $B U M D e s$ is a community economic institution that has a strategic role in improving the economy of rural communities. Therefore, BUMDes needs to optimize its resources for the welfare of the community. The purpose of this community service is to provide assistance, guidance, monitoring of BumDes and to socialize the form of BUMDes development strategy using the Tetrapreneur Model and its development by involving universities and banks. The result of this assistance is that it is hoped that BumDes will be more successful in its activities, because it is assisted by elements of academia and banking. With the existence of an advanced BumDes, the economy of the village community will also increase.
\end{abstract}

Keywords: BUMDes Development Strategy, Tetrapreneur, Higher Education, and Banking 


\section{PENDAHULUAN}

Pembentukan Badan Usaha Milik Desa (BUMDes) telah memiliki payung hukum yang diatur oleh Undang-Undang Nomor 6 tahun 2014 tentang Desa, bunyi pasal tersebut yaitu BUMDes sebagai pelaku ekonomi Desa secara kolektif untuk meningkatkan kesejahteraan Desa dengan mengoptimalkan sumber daya yang dimiliki oleh Desa tersebut. BUMDes menjadi badan usaha milik desa yang pendirian dan pengelolaannya dilakukan oleh Desa, dari Desa dan untuk Desa dimana pelakunya adalah masyarakat pedesaan (Kirowati dan Dwi, 2018). BUMDes salah satu bagian lembaga yang dapat menopang kesejahteran warga Desa, dan tentunya dapat berkontribusi dalam meningkatkan Indeks Pembangunan Manusia (IPM). Pembangunan ketahanan ekonomi Desa untuk mewujudkan kesejahteraan bagi masyarakatnya perlu kesadaran dan upaya bersama oleh semua komponen masyarakat, pemerintah desa maupun para pelaku usaha mikro, makro dan menengah. Dengan adanya kesadaran dan upaya bersama diharapkan dapat memberikan dampak yang signifikan untuk menanggulangi permasalahanpermasalahan yang timbul pada berlangsungnya kegiatan BUMDes sehingga tujuan pendirianya dapat tercapai dengan baik (Fatimah, 2018).

Beberapa permasalahan yang diidentifikasi seperti manajemen pengelolaan produk, permodalan, SDM yang kurang terampil, pemasaran, pemenuhan standar kesehatan dan produk halal, akuntansi dan perpajakan, serta investasi. Bumdes butuh pengembangan daya saing dalam rangka terwujudnya masyarakat desa yang sejahtera dan mandiri. Permasalahan yang sering ditemukan pada proses pengembangan BUMDes adalah manajemen pengelolaan produk, permodalan, SDM yang kurang terampil, pemasaran, pemenuhan standar kesehatan dan produk halal, akuntansi dan perpajakan, serta investasi. Oleh karena itu, BUMDes perlu pengembangan strategi daya saing untuk mencapai masyarakat Desa yang sejahtera dan mandiri. Pentingnya pengelolaan BUMDes di daerah belum disadari oleh manajemen sendiri dan pemerintah daerah (Arman dkk, 2018).

Strategi pengembangan model tetrapreneur merupakan model pengembangan yang harus difokuskan oleh BUMDes dalam meningkatkan daya saing di pasar ekonomi. Tetrapreneur adalah terobosan inovasi Desa yang berbasis empat pilar wirausaha yaitu: (1) Chainpreneur, merupakan rantai pasokan bisnis mulai dari hulu ke hilir; (2) Marketpreneur, adalah sarana bertukarnya nilai produk; (3) Qualitypreneur, yaitu kualitas produk melalui SDM yang berkualitas; dan (4) Brandpreneur, berupa merek produk yang dapat memperkuat posisi strategis dalam pasar ekonomi (Cavinato, 2012). Selain model pengembangan melalui pilar-pilar ekonomi kreatif tersebut, dalam pengembangannya BUMDes juga perlu melakukan kerjasama atau mengadakan kemitraan dengan melibatkan Perguruan Tinggi dan Perbankan. Dengan menjalin mitra dengan Perguruan Tinggi diharapkan dapat melahirkan SDM yang unggul dan kuat dalam bidang akademik yang mampu menciptakan inovasi dan kratifitas dalam persaingan di dunia bisnis. Sedangkan menjalin mitra dengan Perbankan diharapkan dapat menopang dalam sisi financial atau keuangan sehingga dapat mewujudkan optimalisasi peran BUMDes dalam meningkatkan kesejahteran masyarakat Desa (Marsuki, 2005).

Pada intinya bahwa Desa yang mempunyai sumber daya yang luar biasa, akan kalah bersaing jika tidak dapat menciptakan kesejahteraan masyarakatnya di era persaingan bebas yang membutuhkan upaya ide kreatif dalam mengembangkan modal sosial yang dimilikinya. Pengembangan usaha dan perekonomian masyarakat Desa merupakan hal penting untuk diperhatikan, apabila dapat dioptimalkan dengan baik akan 
memberikan dampak yang luar biasa untuk mendorong pertumbuhan ekonomi, serta berkembang dan eksisnya Desa tersebut dan kemudian akan memberikan dampak positif secara nasional dalam menghadapi persaingan pasar bebas (Harmiati dan Zulhakim, 2017).

\section{a. BUMDes}

BUMDes adalah lembaga yang didirikan ditingkat Desa yang difokuskan untuk mengembangkan perekonomian masyarakat Desa dengan menjadikan BUMDes menjadi bagian dari suatu proses produksi bagi produk-produk lokal berbahan baku local (Sumantra dkk, 2016). UU Nomor 32 tahun 2004 dan PP Nomor 72 tahun 2005 mengamanatkan bahwa untuk meningkatkan pendapatan masyarakat dan Desa, pemerintah Desa dapat mendirikan Badan Usaha Milik Desa (BUMDes) sesuai dengan kebutuhan dan potensi Desa. Perencanaan dan pembentukan BUMDes, dibangun atas inisiasi masyarakat, serta mendasarkan pada prinsip-prinsip kooperatif, partisipatif dan emansipatif dimana pengelolaanya dilakukan oleh msyarakat Desa secara gotong royong dan tidak boleh dikuasai oleh pihak tertentu serta harus mementingkan hajat masyarakat Desa (Yudiardi, 2015).

Menurut Dewi dan Meirinawati (2013) menyatakan bahwa hadirnya BUMDes di tengah masyarakat desa memiliki manfaat yang besar yaitu mampu menciptakan lapangan pekerjaan dan mengurangi kemiskinan di tingkat pedesaan. Berikut peran dan fungsi BUMDes diantaranya adalah (Ramadhan dkk, 2013): (1) Meningkatkan perekonomian lokal; (2) Meningkatkan pendapatan Desa; (3) Meningkatkan pendapatan masyarakat Desa. Sedangkan Menurut Gunawan (2011), BUMDes memiliki peranan diantaranya adalah dapat mengurangi laju urbanisasi serta mendorong berkembangnya ekonomi masyarakat Desa dengan memanfaatkan sumber daya yang dimiliki oleh Desa.

Tujuan kegiatan didirikannya BUMDes yaitu: (1) Membentuk unit-unit usaha masyarakat Desa; (2) Memberikan pelatihan ketrampilan untuk membuat produk lokal yang memiliki daya saing kuat; (3) Memberikan pemahanan mengenai pengelolaan, proses produksi dan standarisasi produk di masing-masing unit; (4) Menyamakan pandangan mengenai kegiatan yang dijalankan sesuai dengan devisi pada kelompok Desa berbeda (Sumantra, 2016). Dengan adanya fungsi dan tujuan tersebut, diharapkan BUMDes dapat memberikan dampak yang signifikan untuk meningkatkan ekonomi nasional, dimana pemerintah melakukan pembangunan sentral ekonomi dimulai dari tingkat Desa untuk mewujudkan masyarakat yang adil dan makmur sesuai dengan amanta UUD 1945 (Furqon dkk, 2018).

\section{b. Model Tetrapreneur}

Tetrapreneur merupakan sebuah teori dalam melakukan pengembangan dan peningkatan usaha dengan menggunakan pendeketan-pendekatan melalui 4 (empat) faktor dasar yang terdiri dari Chainpreneur, Marketpreneur, Qualitypreneur, dan Brandpreneur (Fatimah, 2018) 


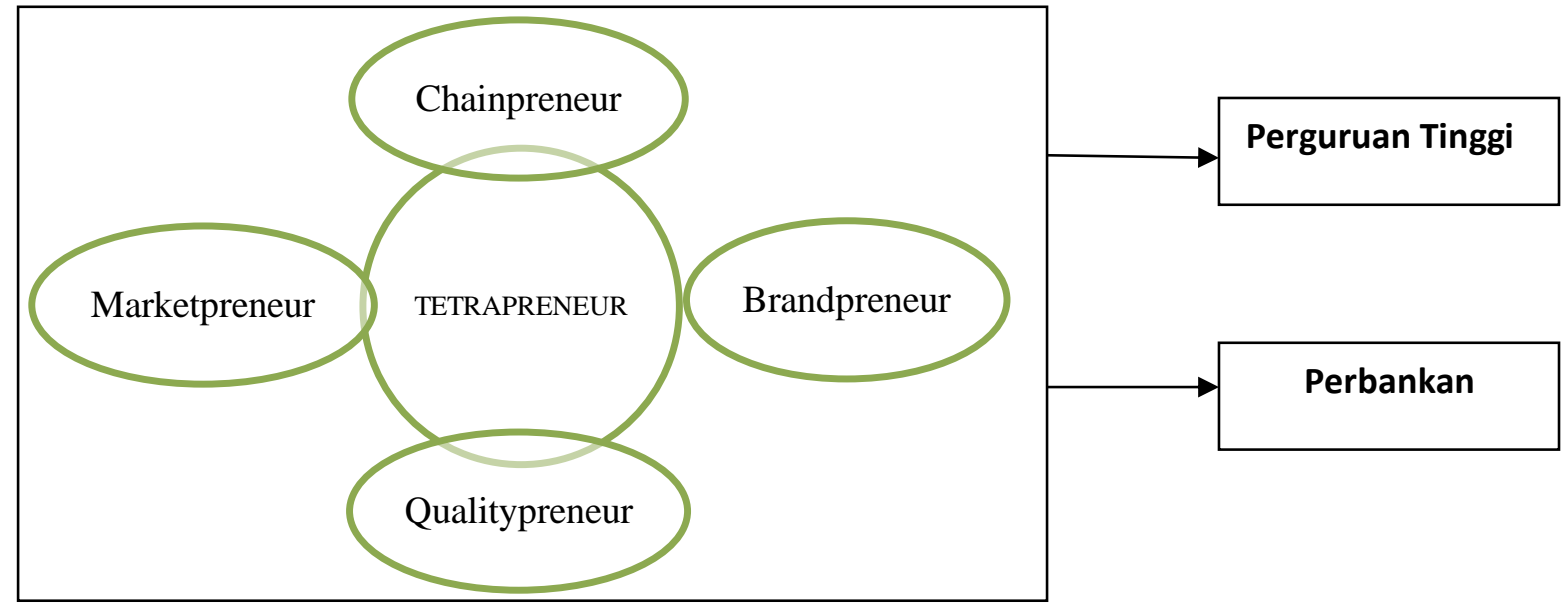

Gambar 1. Pengembangan Model Tetrapreneur dan Kemitraan pada

Perguruan Tinggi \& Perbankan

\section{Chainpreneur}

Chainpreneur atau yang disebut dengan Rantai Wirausaha merupakan suatu pendekatan untuk mendeskripsikan bagaiaman rantai kewirausahaan itu berlangsung atau bagaiaman suplai distribusi dari produk-produk yang dipasarkan yang terdiri dari semua pihak, baik secara langsung maupun tidak langsung dengan tujuan untuk memenuhi kebutuhan dan keinginan pelanggan (Fatimah, 2018). Tujuan dengan adanya rantai pasokan diharapkan dapat memberikan nilai surplus dari setiap produk yang didistribusikan dipasaran (Cavinato, 2012).

\section{Marketpreneur}

Marketpreneur (Pasar Wirausaha) merupakan sebuah sudut pandang yang inovatif mengenai kondisi yang ada di pasar usaha terkait dengan kebutuhan para pengusaha untuk memenuhi keinginan dan kebutuhan konsumen secara keseluruhan. Untuk mempertahankan nilai profitabilitas, dalam berbisnis harus sadar bagaiamana caranya dapat mengahsilkan produk yang berkualitas dan efesiensi beroperasi sehingga dapat menguasai pasar ekonomi yang bertanggung jawab baik kepada konsumen, investor, regulator maupun pemerintah (Ferrel dkk, 2014).

\section{Qualitypreneur}

Qualitypreneur (Kualitas Wirausaha) merupakan sebuah rekomendasi bagaimana seorang pengusaha mampu menghasilkan usaha yang berkualitas sehingga dapat bertahan dengan segala keadaan. Biasanya ukuran untuk menilai tingkat kualitas sebuah usaha dilihat dari karakteristik dan inovasi yang dimiliki wirausaha dalam memenuhi kebutuhan dan keinginannya yang tesirat maupun tersurat (Sower, 2011).

\section{Brandpreneur}

Brandpreneur (Merek Usaha) merupakan pendekatan berkaitan dengan nilai merek suatu produk yang ada di pasar ekonomi. Benchmarking adalah salah satu teknik wirausaha global yang terkenal untuk mendorong pertumbuhan usaha melalui pendekatan nilai merek sehingga dengan brand/merek yang dimiliki produk yang dihasilkan wirausaha dapat berkompetisi dengan produk yang lain dipasar ekonomi 
secara khas dan mampu mendapatkan posisi yang strategis di pasar dan mempertahankan siklus hidupnya (Keller dkk, 1992).

\section{A. Modal Sosial}

Modal sosial merupakan sebuah teori baru untuk mengukur kualitas hubungan di dalam sebuah organisasi, komunitas maupun masyarakat. Modal sosial meliputi hubungan sosial, norma sosial maupun kepercayaan. Dapat didefinisikan bahwa modal sosial merupakan sebuah aturan main dan interaksi di masyarakat untuk mengelola sebuah lingkungan yang efektif dan kondusif (Kirowati dan Dwi, 2018). Modal Sosial menjadi salah satu unsur penting di masyarakat yang berfungsi untuk mengelola efisiensi ekonomi dan tidak mudah dibentuk melalui kebijakan publik. Dalam penerapannya, modal sosial harus mengarah kepada kerjasama atau gotong royong di dalam kelompok sehingga berhubungan dengan tanggung jawab dan kejujuran dalam menjalankan tugas secara konsisten, hubungan timbal balik dan lain sebagainya (Fatimah, 2018).

\section{B. Pengembangan dan Pemberdayaan Masyarakat}

Menurut Midgley, 1995 (dalam Kirowati dan Dwi, 2018) menjelaskan bahwa dasar dalam pembangunan ekonomi dalam suatu Desa yaitu dengan melakukan pengembangan dan pemberdayaan masyarakat. Pengembangan dan pemberdayaan memiliki fungsi untuk menumbuhkan suatu kesadaran mengenai kemampuan yang dimiliki individu dan bagaimana caranya untuk mengembangkan kemampuan tersebut agar lebih bermanfaat serta mengidentifikasi permasalahan-permasalahn yang ada dan mencari cara untuk menanggulanginya. Ini merupakan sebuah langkah dalam mempersiapkan masyarakat yang memiliki kemampuan dan keberanian sikap kritis dalam kondisi yang dihadapi sehingga mampu mewujudkan kemajuan, kemandirian dan kesejahteraan masyarakat yang berkelanjutan (Dariah, 2009).

\section{Perguruan Tinggi}

Menurut Undang-Undang Nomor 22 Tahun 1961 tentang Perguruan Tinggi, menjelaskan bahwa definisi dari Perguruan Tinggi adalah lembaga ilmiah yang mempunyai tugas menyelenggarakan pendidikan dan pembelajaran diatas tingkat pendidikan menengah atas sesuai dengan kebudayaan kebangsaan Indonesia dan dengan cara ilmiah. Perguruan Tinggi memiliki beberapa fungsi, diantaranya adalah (UU No. 12 Tahun 2012 Pasal 4):

1. Mengembangkan kemampuan dan membentuk watak serta peradaban bangsa yang bermartabat dalam rangka mencerdaskan kehidupan bangsa.

2. Mengembangkan Sivitas Akademika yang inovatif, responsif, kreatif, terampil, berdaya saing, dan kooperatif melalui pelaksanaan Tridharma, dan

3. Mengembangkan Ilmu Pengetahuan dan Teknologi dengan memperhatikan dan menerapkan nilai Humaniora.

Perguruan Tinggi juga harus mengimplementasikan Tridharma Perguruan Tinggi, yaitu Pendidikan dan Pengajaran, Pengembangan dan Penelitian serta Pengabdian kepada Masyarakat. Untuk point pengabdian kepada masyarakat diharapkan dapat memberikan ide-ide atau inovasi untuk pengembangan produk-produk yang dihasilkan oleh BUMDes maupun mampu melahirkan SDM yang unggul untuk mengelola BUMDes secara maksimal (Wibawa, 2017). 


\section{Lembaga Keuangan Perbankan}

Lembaga keuangan perbankan merupakan sebuah lembaga yang memberikan pelayanan dalam penyediaan keuangan bagi para nasabahanya yang diatur oleh regulasi keuangan dari pemerintah. Lembaga keuangan perbankan memiliki 3 (tiga) jenis lembaga diantaranya adalah :

1. Bank Sentral, merupakan suatu lembaga yang mengatur keseluruhan perputaran uang disuatu Negara dan lembaga yang bertanggungjawab dalam menstabilkan nilai kurs mata uang. Di Indonesia bank sentral dipegang oleh Bank Indonesia.

2. Bank Umum, merupakan suatu lembaga yang menjembatani semua pihak yang membutuhkan dana atau yang memiliki dana. Dana yang dihimpun dari masyarakat nantinya akan kembali kepada masyarakat baik individu maupun perusahaan yang membutuhkan modal.

3. Bank Perkreditan Rakyat, merupakan salah satu lembaga yang hanya memberikan modal usaha yntuk masyarakat, selain itu BPR hanya menerima simpanan dalam bentuk deposito ataupun tabungan dan biasanya BPR terletak pada masyarakat yang membutuhkan modal untuk usaha.

\section{METODE PELAKSANAAN}

BUMDes merupakan suatu lembaga yang berada di desa. Hadirnya BUMDes di tengah masyarakat desa memiliki manfaat yang besar yaitu mampu menciptakan lapangan pekerjaan dan mengurangi kemiskinan di tingkat pedesaan. Dengan adanya BUMDes, desa memiliki keunggulan yang bisa menjadi daya tarik bagi investor. Berbagai bentuk ungulan yang bisa dihasilkan oleh BUMDes bisa berbagai macam, seperti pengelolaan pariwisata terpadu, produk unggulan desa, dan komoditi lain yang bisa ditawarkan ke pihak luar. Pemilihan lokasi pendampingan BumDes ada di desa Sawojajar Kecamatan Wanasari Kabupaten Brebes. Pemilihan lokasi ini didasari desa yang mempunyai banyak keunggulan tapi belum dilakukan secara maksimal.

Kegiatan pengabdian pada masyarakat, berupa pendampingan awal BumDes yang mandiri, pelatihan, pembuatan program serta pengadaan fasilitas untuk mendukung berkembangya BUMDes. Skema strategi pengembangan kualitas BUMDes melalui Model Tetrapreneur dan kemitraan dengan Perguruan Tinggi serta Perbankan dilakukan dengan pendekatan teori yang sudah dijelaskan sebelumnya. Beberapa tahapan yang akan dilakukan pada penelitian ini diantaranya adalah pembahasan mengenai:

a. Peningkatan kualitas BUMDes melalui perbaikan Rantai Wirausaha atau Chainpreneur, dimana pendekatan ini lebih memfokuskan bagaimana rantai pemasok terjalin dengan baik sehingga produk yang di distribusikan berjalan dengan baik.

b. Peningkatan kualitas BUMDes melalui perbaikan Pasar Wirausaha atau Marketpreneur, dimana pendekatan ini difokuskan bagaimana produk mampu masuk dalam segmen pasar dan memiliki daya saing yang kuat dan minat konsumen yang baik.

c. Peningkatan kualitas BUMDes melalui perbaikan Kualitas Wirausaha atau Qualitypreneur, dimana pendekatan ini difokuskan mengenai perbaikan pelayanan. Pelayanan yang baik akan menarik para konsumen dan mencerminkan bahwa kualitas wirausaha yang dimiliki suatu badan usaha sudah berjalan dengan baik. 
d. Peningkatan kualitas BUMDes melalui perbaikan Merek Usaha atau Brandpreneur, dimana pendekatan ini difokuskan pada merek/brand dari suatu produk atau sebuah kakrakteristik yang kuat mengenai badan usaha tersebut. Artinya ketika badan usaha sudah memiliki karakteristik yang khas dan merek/brand yang kuat dipasaran, maka konsumen akan selalu mudah mengingatnya dan cenderung akan banyak diminati dipasaran.

e. Peningkatan kualitas BUMDes melalui kemitraan dengan Perguruan Tinggi, dimana Perguruan Tinggi pada penelitian ini diposisikan sebagai lembaga pendidikan dan pengembangan yang diharapkan dapat melahirkan SDM yang unggul dan inovatif untuk mengelola BUMDEs.

a. Peningkatan kualitas BUMDes melalui kemitraan dengan Perbankan. Sesuai dengan fungsi dari perbankan yaitu sebagai pihak yang memberikan pelayanan terkait dengan keuangan, maka menjalin kemitraan dengan Perbankan diharapkan mampu mencukupi sumber dana BUMDes dalam menjalankan operasionalnya.

\section{HASIL DAN PEMBAHASAN}

Sistem perekonomian di Indonesia mulai memasuki era yang baru setelah diterbitkannya Undang-Undang yang mengatur mengenai pendirian BUMDes. Dengan legalnya badan usaha di tingkat desa ini, perekonomian Indonesia di fokuskan pengembangannya melalui elemen masyarakat pedesaan (Furqon dkk, 2018). Dengan adanya regulasi yang kuat dari pemerintah, diharapkan BUMDes mampu memberikan dampak yang positif mengenai peningkatan perekonomian dan kesejahteraan di masyrakat pedesaan sehingga mampu memberikan dampak ekonomi secara nasional. Untuk mewujudkan tujuan tersebut, tentunya BUMDes harus memilik tata kelola yang baik dan menghasilkan produk-produk lokal yang dapat bersaing di pangsa pasar (Bambang, 2017). Berikut ini pembahasan dari hasil penelitian ini adalah:

\section{Pengukuran kualitas BUMDes melalui Chainpreneur (Rantai Wirausaha)}

Pada identifikasi permasalahan yang ada dilapangan bahwa fakta yang terjadi proses produksi dilakukan jika hanya ada pesanan dari pelangan. Sebagian masyarakat mengaku bahwa keterbatasan informasi turut menyebabkan proses produksi yang sedikit sehingga menghambat pengembangan bisnis secara meluas. Adapun akses utama yang dibutuhkan dalam operasional BUMDes diantaranya adalah (1) Informasi mengenai bahan baku; (2) Pelanggan/pasar; dan (3) Akses pembiayaan.

Informasi dari hulu ke hilir sangat dibutuhkan untuk proses produksi dan pemasarannya, dimana pengelola menginginkan kemudahan dalam mendapatkan bahan baku yang berkualitas dengan biaya yang hemat untuk menghasilkan produk yang terbaik. Setelah proses produksi selesai, tahap selanjutnya yang dinginkan adalah pemasok atau distributor yang membantu menampung dan memasarkan produknya masih sedikit sehingga pendistribusian produk untuk sampai ke pasar dan pelanggan terhambat, artinya rantai wirausaha masih belum terhubung dengan baik.

Strategi produksi yang tepat diharapkan mampu mengurangi permasalahan yang terjadi. Temuan selanjutnya dalam penelitian ini adalah kesesuaian keinginan masyarakat mengenai harga produk yang sama atau lebih rendah dibandingkan dengan pasar dapat menjadikan peluang pada saat proses produksi dengan memilih bahan baku yang dapat disesuaikan dengan keingan tersebut. Kesesuaian pengadaan bahan baku, proses produksi 
dan penentuan harga produk akan menjaga keberlangsungan usaha. Proses produksi yang hanya mengandalkan keinginan dari masyarakat memberikan keuntungan berupa produksi yang tidak berlebihan dan penumpukan bahan baku yang berlebihan tidak tejadi seiring dengan masih kurangnya rantai wirausaha yang masih belum terjalin dengan baik untuk pendistribusian produk.

\section{Pengukuran kualitas BUMDes melalui Marketpreneur (Pasar Wirausaha)}

Pada identifikasi kebutuhan pasar yang dibutuhkan oleh pelaku usaha adalah mengenai informasi segmen pasar untuk keberlanjutan dan pengembangan bisnis mereka. Fakta dilapangan masih ditemukan bahwa masih banyak pelaku usaha yang belum mampu mendapatkan informasi mengenai segmen pasar yang akan mereka masuki produknya. Dengan adanya permasalahan tersebut para pelaku usaha masih kesulitan unuk memasarkan porduknya di segemen pasar. Hal ini sangat mengkhawtirkan, mengingat segmen pasar merupakan hal yang penting dalam proses pengembangan usaha, dimana ketika produk sudah menemukan segmen pasarnya maka para pelaku usaha akan dengan mudah memasarkan produknya.

Identifkasi lain mengenai segmen pasar untuk meningkatkan penjualan, para pelaku usaha mengaku lebih mudah memasuki segmen pasar ketika menjelang hari raya, akhir tahun atau hari-hari besar. Pemerhatian pasar pada momen tertentu secara konsisten terjadi, artinya setiap terjadi momen-moment tersebut daya beli masyarakat meningkat sehingga mampu menaikkan nilai penjualan. Selanjutnya ada potensi keberlanjutan untuk segmen pasar, para pelaku usaha perlu responsive untuk mencari segmen pasar dan diharapkan tidak menunggu pesanan untuk proses produksi karena pada dasarnya konsumen menginginkan selalu tersedianya produk yang diinginkan di segmen pasar.

\section{Pengukuran kualitas BUMDes melalui Qualitypreneur (Kualitas Wirausaha)}

Dalam pengukuran Qualitypreneur atau Kualitas Wirausaha dapat dilihat dari 3 (tiga) aspek diantaranya adalah kualitas wirausaha keseluruhan, kualitas professional social skill dan kualitas professional social skill muda. Kualitas Wirausaha Keseluruhan, para pelaku usaha berada pada kondisi yang nyaman hal ini di lihat dari ketika adanya peningkatan laba tidak dimanfaatkan dengan baik untuk meningkatkan pertumbuhan penjualan dan tenaga kerja, sehingga mengakibatkan kurangnya ekspansi bisnis untuk produk Desa yang ada. Kemungkinan tidak dilakukannya ekspansi bisnis adalah karena ketidatahuannya mengenai segmen pasar yang tepat untuk produknya. Hal ini sejalan dengan teori sebelumnya terkait dengan Fakta Pasar. Untuk mengatasi permasalahan ini adalah dengan memanfaatkan SDM yang memiliki pengalaman bekerja dan memiliki jenjang pendidikan yang baik. Diharapkan dengan adanya SDM yang unggul dan bepengalaman dapat memberikan terobosan baru untuk melakuka ekspansi bisnis sehingga dapat menjaga keberlangsuan usaha tersebut.

Kualitas Professional Social Skill, diidentifikasikan dengan membandingkan kapasitas yang dimiliki oleh para pelaku usaha. Performa dan pelayanan yang diberikan dapat menjadi ukuran profesional pelaku usaha dalam menjalankan usahanya. Performa dan pelayanan yang baik menggambarakan bahwa pelaku usaha sudah memiliki pemahaman yang lebih mengenai ilmu kewirausahaan dan pengembangan bisnis. Keinginan dan kemauan dari para pelaku usaha menjadi faktor utama dalam meningkat kualitas profesional wirausaha. Kualitas Professional Social Skill Muda, identifikasi terkait dengan hal ini adalah mengenai para pelaku usaha yang masih berusia muda. Dimana pada usia muda para pelaku bisnis memiliki kemauan yang kuat untuk beriwirausaha namun masih kurangnya pemahaman mengenai teori dasar wirausaha. Ini 
bisa menjadi potensi yang baik untuk sebuah Desa apabila peran pemuda dapat dioptimalkan dengan baik dalam dunia bisnis. Oleh karena itu, pelatihan-pelatihan berwirausaha perlu ditingkatkan lagi untuk melahirkan pemuda desa yang memiliki kemampuan untuk mengembangkan bisnisnya.

\section{Pengukuran kualitas BUMDes melalui Brandpreneur (Merek Wirausaha)}

Pada identifikasi temuan dilapangan bahwa fakta yang ada merek/brand yang dihasilkan masih belum mampu menembus segmen pasar. Oleh karena itu masih perlu adanya inovasi atau terobosan baru untuk mengatasi permasalahan ini. Akan menjadi potensial jika ketika secara benar hasil dari program-program yang diselenggarakan oleh pemerintah dapat diimplementasikan untuk menciptakan brand/merek yang sesuai dengan keadaan desa tersebut. Dengan memperbanyak informasi yang didapatkan mengenai keadaan Desa maupun dari luar diharapkan dapat dikombinasikan untuk mencipatakan sebuah brand/merek yang dapat digunakan untuk mengembangkan bisnis secara meluas.

\section{Pengukuran kualitas BUMDes melalui kemitraan dengan Perguruan Tinggi}

Perkembangan BUMDes harus dapat mengikuti perkembangan teknologi yang semakin pesat. Dengan hadirnya Perguruan Tinggi menjadi mitra BUMDes diharapkan dapat membantu memberikan inovasi terkait penggunaan teknologi dalam proses pengembangan bisnisnya. Identifikasi di lapangan ditemukan bahwa eksistensi Perguruan Tinggi berperan sangat penting dalam pengembangan usaha di desa. Melalui Tri Dharma Perguruan Tinggi para intelektual mau mengabdikan diri kepada masyarakat dan memberikan ilmu yang didapatkan untuk berkembangan usaha di pedesaan. Melalui kegiatan KKN misalnya, para mahasiswa yang masih aktif dalam perkuliahan mampu memberikan inovasi atau ide baru untuk menghasilkan produk dari sumber daya yang ada di Desa dan kemudian memberikan pemahaman mengenai pemanfaatan teknologi untuk proses pemasaran produk. Dengan begitu para pelaku usaha mempunyai pengetahuan dan kemudahan mencari informasi terkait dengan kebutuhan-kebutuhan di pasar.

Selain itu juga, melalui Perguruan Tinggi dapat memberikan pelatihan-pelatihan mengenai manajemen organisasi, akuntansi dan pembuatan laporan keuangan usaha. Sehingga dengan adanya kemitraan yang baik antara BUMDes dan Peguruan Tinggi dapat mewujudkan SDM yang inovatif dan unggul serta mampu mengelola dan menghasilkan kegiatan usaha yang berdaya saing tinggi. Dengan begitu fungsi dan peran BUMDes dalam mewujudkan kesejahteraan masyarakat dengan meningkatkan perekonomian di Desa dapat tercapai dengan mudah.

\section{Pengukuran kualitas BUMDes melalui kemitraan dengan Perbankan}

Menjalankan sebuah usaha tidak lepas dari adanya sumber dana yang medukung. Hadirnya Perbankan sebagai lembaga keuangan yang memberikan jasa pelayanan simpan pinjam dirasakan manfaatnya oleh para pelaku bisnis. Identifikasi masalah dilapangan mengungkapkan bahwa para pelaku usaha sangat terbantu dalam mencari sumber dana untuk mengembangkan bisnisnya. Melalui program KUR, masyarakat dapat memiliki modal usaha dengan bunga yang rendah, artinya untuk badan usaha Desa atau BUMDes tidak mempunyai alasan untuk tidak memiliki sumber dana yang cukup untuk pengembangan bisnis. Hubungan kemitraan antara BUMDes dan Perbankan harus tetap terjaga, karena dengan kepercayaan yang diberikan oleh Perbankan terkait dengan keuangan dapat dimanfaatkan untuk proses pengembangan usaha secara berkelanjutan 
sehingga diharapkan selama berjalannya usaha tidak akan kesulitan dalam mencari sumber dana. Perbankan dalam dunia usaha memiliki peran yang sangat penting, oleh karena itu untuk membantu pemerintah dalam meningkat kesejahteraan masyarakatnya melalui kegiatan usaha, Perbankan mempermudah regulasi proses peminjaman untuk kegiatan usaha bahkan untuk masyarakat kecilpun bisa mendapatkan sumber dana untuk berwirausaha selagi mempunyai kemauan dan tekad yang kuat untuk mengembangkan usaha di Desa.

\section{KESIMPULAN}

Strategi pengembangan kualitas BUMDes melalui pendekatan dengan model Tetrapreneur dapat untuk mengidentifikasi permasalahan-permasalahan yang muncul dilapangan. Perbaikan dan solusi dari semua temuan yang ada, perlu adanya langkah yang konkrit dari pihak-pihak yang terlibat terutama adalah Pemerintah Desa selaku pemangku kepentingan (kebijakan). Perlu adanya pelatihan, pembuatan program serta pengadaan fasilitas-fasilitas untuk mendukung berkembangya BUMDes.

Peran aktif Perguruan Tinggi dan Perbankan membantu pengembangan BUMDes dalam segi SDM dan financial. SDM yang unggul dan inovatif tentu sangat memberikan dampak yang positif untuk perkembangan unit usaha dengan menghasilkan produk maupun ide-ide pemasaran yang mampu menembus segmen pasar global dan mampu berdaya saing dengan produk-produk yang lainnya serta SDM yang mampu mengelola organisasi dengan baik. Sumber dana yang mudah didapatkan dapat mendukung berlangsungya kegiatan usaha, sehingga tak ada lagi usaha-usaha yang berhenti karena kurangnya modal untuk berkembang menjadi unit usaha yang maju dan mandiri.

\section{REKOMENDASI}

a. BUMDes yang berkelanjutan harus mampu meningkatkan kesejahteraan masyarakat melalui pengembangan potensi yang ada di Desa.

b. Proses pengembangan unit usaha BUMDes harus memperhatikan aspek-aspek yang telah di jelaskan sebelumnya dengan selalu melakukan perbaikan-perbaikan pada Rantai Wirusaha, Pasar Wirausaha, Kualitas Wirausaha dan Merek Wirausaha sehingga dengan tercapainya semua aspek tersebut BUMDes dapat menjadi badan usaha yang lebih maju dan kompetitif

c. Dalam meningkatkan pengelolaan, BUMDes harus terus meningkat kemampuan SDM yang dimiliki dan bekerja sama dengan Perguruan Tinggi maupun Dinas terkait untuk melakukan pendampingan.

d. Dalam memperkuat peran SDM dalam pengelolaan BUMDEs, seyogyanya manajemen diisi oleh orang-orang yang profesional dan ahli dibidangnya masingmasing.

e. Untuk menjaga sumber dana untuk kegiatan operasi, BUMDes harus tetap menjalin hubungan yang baik dengan lembaga-lembaga keuangan baik itu perbankan maupun lembaga keuangan non-bank. 


\section{DAFTAR PUSTAKA}

Arman, A., Marsuki., \& Sulkipi. (2018). Model Pengembangan Bumdes Melalui Kemitraan Perguruan Tinggi dan Perbankan. Proceeding of Community Development. Vol. 2, 520-526.

Bambang, B. (2017). Implemetasi Badan Usaha Milik Desa Berbasis Ekonomi Islam: Suatu Kajian Elementer. Jurnal Iqtisaduna, 3(2), 109-131.

Cavinato, J.L. (2002). “What's your Supply Chain type?” Supply Chain Management Review May-June: 60-66.

Dariah, A. R. (2009). Peran Perguruan Tinggi dalam Aplikasi Variasi Model Pemberdayaan Masyarakat Desa di Jawa Barat. MIMBAR: Jurnal Sosial dan Pembangunan, 25(2), 143-152.

Dewi, Y. S. R. (2013). Strategi Pembangunan Desa Dalam Mengentaskan Kemiskinan Desa Melalui Badan Usaha Milik Desa (BUMDes)(Studi Pada Program Usaha Agrobisnis Pertanian (PUAP) Di Desa Sareng Kecamatan Geger Kabupaten Madiun. Skripsi. Fakultas Ilmu Sosial dan Hukum Universitas Negeri Surabaya. Surabaya.

Fatimah, P. R. (2018). Mengembangkan Kualitas Usaha Milik Desa (Q-BUMDES) untuk Melestarikan Ketahanan Ekonomi Masyarakat dan Kesejahteraan Adaptif: Perancangan Sistem Kewirausahaan Desa dengan Menggunakan Model Tetrapreneur. Jurnal Studi Pemuda, 7(2), 122-132.

Ferrel and O. C. (2014). Business. USA: Mc-Graw Hill.

Furqan, A. M., \& Fahmi, R. A. (2018). Peluang Pengembangan Ekonomi Islam Melalui Badan Usaha Milik Desa (BUMDes).

Gunawan, K. (2011). Manajemen BUMDes dalam rangka menekan laju urbanisasi. Jurnal. WIDYATECH Jurnal Sains dan Teknologi, 10(3).

Harmiati, A. A. Z., Zulhakim, A. A., \& Sos, S. (2017). Eksistensi Badan Usaha Milik Desa (BUMDes) Dalam Mengembangkan Usaha dan Ekonomi Masyarakat Desa yang Berdaya Saing di Era Masyarakat Ekonomi ASEAN. Retrieved from: Jurnal Unihaz Bengkulu, Cluster Ekonomi. Setnas ASEAN.

Keller, K. L., \& Aaker, D. A. (1992). The effects of sequential introduction of brand extensions. Journal of marketing research, 29(1), 35-50.

Kirowati, D., \& dwi Setia, L. (2018). Pengembangan Desa Mandiri melalui BUMDes dalam Meningkatkan Kesejahteraan Masyarakat Desa (Studi Kasus: Desa temboro Kecamatan Karas Kabupaten Magetan). Jurnal AKSI (Akuntansi dan Sistem Informasi), 3(1), 15-24. 
Marsuki (2005). Analisis Sektor Perbankan, Moneter dan Keuangan Indonesia, Edisi Pertama. Jakarta: Mitra Wacana Media

Sower, V. E. (2010). Essentials of quality with cases and experiential exercises. John Wiley \& Sons.

Sumantra, K., Yuesti, A., Suryatmaja, I. B., \& Sudiana, A. K. (2016). Pemberdayaan Kelompok Ekonomi Produktif Pendukung Badan Usaha Milik Desa (Bumdes) Di Desa Pajahan Dan Munduk Temu Kecamatan Pupuan, Tabanan. Prosiding Semnas Hasil Pengabdian Masyarakat.

Wibawa, S. (2017). Tridharma Perguruan Tinggi (Pendidikan Dan Pengabdian Kepada Masyarakat). Disampaikan dalam Rapat Perencanaan Pengawasan Proses Bisnis Perguruan Tinggi Negeri. Yogyakarta, 29, 01-15.

Yudiardi, D. (2015). Strategi Pengembangan Badan Usaha Milik Desa (BUMDes) Dalam Meningkatkan Perekonomian Masyarakat Pedesaan Kabupaten Garut. Jurnal Fakultas Ilmu Sosial Politik Universitas Garut. 